\title{
Retraction Note: On the fourth power mean of the two-term exponential sums
}

Minhui Zhu' and Di Han ${ }^{2 *}$

\section{"Correspondence:} handi515@163.com

${ }^{2}$ Department of Mathematics, Northwest University, Xi'an, Shaanxi, P.R. China

Full list of author information is available at the end of the article

\section{Abstract}

This is a retraction of the article submitted by Zhu and Han (J. Inequal. Appl. 2014:116, 2014).

\section{Retraction}

Following publication of this article [1], it was brought to the attention of the editorial and publishing staff that an identically-titled article by Han Zhang and Wenpeng Zhang [2] was published in January 2014 in The Scientific World Journal.

This is a violation of publication ethics which, in accordance with the Springer Policy on Publishing Integrity, warrants a retraction of the article and a notice to this effect to be published in the journal.

\section{Author details}

'School of Science, Xi'an Polytechnic University, Xi'an, Shaanxi, P.R. China. ${ }^{2}$ Department of Mathematics, Northwest University, Xi'an, Shaanxi, P.R. China.

Received: 1 August 2014 Accepted: 1 August 2014 Published: 03 Sep 2014

\section{References}

1. Zhu, M, Han, D: On the fourth power mean of the two-term exponential sums. J. Inequal. Appl. 2014, 116 (2014)

2. Zhang, H, Zhang, W: On the fourth power mean of the two-term exponential sums. Sci. World J. 2014, 724840 (2014)

10.1186/1029-242X-2014-344

Cite this article as: Zhu and Han: Retraction: On the fourth power mean of the two-term exponential sums. Journal of Inequalities and Applications 2014, 2014:344

Submit your manuscript to a SpringerOpen ${ }^{\circ}$ journal and benefit from:

- Convenient online submission

Rigorous peer review

- Immediate publication on acceptance

Open access: articles freely available online

- High visibility within the field

Retaining the copyright to your article

Submit your next manuscript at $>$ springeropen.com

2014 Zhu and Han; licensee Springer. This is an Open Access article distributed under the terms of the Creative Commons Attribution License (http://creativecommons.org/licenses/by/2.0), which permits unrestricted use, distribution, and reproduction in any medium, provided the original work is properly cited. 